\begin{abstract}
JAROSLAV PÁNEK
Instytut Historii Czeskiej Akademii Nauk, Praga
\end{abstract}

\title{
EUROPA ŚRODKOWA - TYSIĄCLETNIE STARANIA O PRZETRWANIE W RÓWNOWADZE
}

Jedynym relatywnie mocnym punktem, na którym może się opierać pojęcie Europy Środkowej, jest moim zdaniem położenie geograficzne w środku kontynentu. Wprawdzie brak jednoznacznego stanowiska w kwestii tego, gdzie dokładnie ów punkt środka się znajduje, ale dokonując stosunkowo prostego rozdzielenia Europy według stron świata, można zauważyć, że chodzi tu o kraje, które nie leżą ani na zachodzie czy wschodzie, ani też na północy czy południu naszego kontynentu; że zatem obszar Europy Środkowej w przybliżeniu można wyznaczyć kilkoma współczesnymi państwami - Polską, Czechami, Słowacją, Węgrami, Austrią i Słowenią. Wszystkie pozostałe koncepcje Europy Środkowej są stale na nowo tworzonymi i wciąż na nowo podawanymi w wątpliwość konstruktami, czerpiącymi z historii filozofii oraz uwzględniającymi interesy polityczne, ekonomiczne, kulturowe bądź inne. Mamy tu także do czynienia z odrobiną poezji, skażonej jednak kroplą propagandy, kiedy niektóre kraje same siebie określają rzeczywistym środkiem czy sercem Europy. Odwołują się przy tym do zakorzenionego, a nieuzasadnionego wyobrażenia, że bycie w centrum kontynentu jest jakimś udogodnieniem, aczkolwiek spojrzenie za Ural i za Ocean Atlantycki świadczy o czymś zupełnie odwrotnym. Jakich korzyści dostarcza bowiem Mongolii i pustyni Gobi położenie w umownym centrum Azji, Republice Środkowej Afryki umiejscowienie w środku Afryki, „republikom bananowym” usytuowanie między Ameryką Północną i Południową czy Wielkiej Pustyni Piaszczystej lokalizacja mniej więcej w centrum Australii?

Uznanie faktu, że stanowimy część Europy Środkowej, oznacza więc jedynie uświadomienie sobie w większym lub mniejszym stopniu neutralnych wyznaczników geograficznych. Konceptualizacja - i to nie 
tylko dla historyka - zaczyna się dopiero w chwili, kiedy to pojęcie staramy się wypełnić także innymi treściami aniżeli treści fizyczno-geograficzne. Nie musi przy tym chodzić jedynie o samoprezentację, czyli kryterium samoświadomości mieszkańców danego regionu w danej epoce, jaką w przeszłości i współcześnie widzimy na przykład na Dalekim Wschodzie, gdzie kontynentalne Chiny były i są w oczach swoich władców i mieszkańców „państwem środka (świata)”, podczas gdy Tajwan uchodzi za „serce Azji”. Tego rodzaju autostereotypy i heterostereotypy odgrywają w wizjach człowieka o pojęciu „środka” znaczną rolę, ale dla historyka powinny być raczej przedmiotem badań krytycznych aniżeli wskazówką podczas jego rozważań. Umowne oznaczenie może z pewnością wywierać wpływ na zbiorową świadomość mieszkańców określonego kraju czy państwa, ale ma niewielkie znaczenie dla oceny jego realnego miejsca w ramach kontynentu czy świata.

Regionalny podział Europy i świata zajmuje jednak w historiografii ważne miejsce i przyczynia się nie tylko do konceptualizacji, ale także do niezbędnego strukturalnego porządkowania historii jako systematycznej pracy z niezliczoną ilością cząstkowych sprawdzonych faktów, niepotwierdzonych danych, przypuszczeń i hipotez o charakterze historycznym i historiograficznym. Pewna „regionalizacja” historii jest absolutnie nieodzownym narzędziem pracy historyka, którego tok myślenia przebiega nie tylko w sferze czasu, ale też w sferze przestrzeni. Oczywiście od niego zależy, w jaki sposób tę regionalizację przeprowadzi, jak ją uzasadni i jakie kryteria rozczłonkowania przestrzeni wybierze do swoich badań. $\mathrm{Z}$ tego punktu widzenia jest możliwe, aby historyk tworzył własną - odmienną od pozostałych historyków - koncepcję centrum, peryferii czy semiperyferii i aby konstruował na przykład „historię europejskiej peryferii”, w której porównywałby kraje Europy Środkowej z Irlandią, Szkocją, Portugalią itd. Taki badacz prawdopodobnie ustaliłby niektóre strukturalne analogie krajów, które zostały usunięte w cień lub znajdowały się pod naciskiem mocarstw regionalnych, ale bez wątpienia musiałby stwierdzić także całkowicie zasadnicze różnice, wynikające z wyznaczników geograficznych i historycznych. Wymienię jedynie specyficzne komunikacyjne możliwości krajów leżących nad Oceanem Atlantyckim, warunki egzystencji małego narodu portugalskiego pozwalające mu na zbudowanie imperium kolonialnego i utworzenie ogromnego zaplecza luzytańskiego w Ameryce Południowej, udział Szkotów i Irlandczyków w rozwoju Imperium Brytyjskiego czy konsekwencje kulturowe przyjęcia języka angielskiego jako języka światowego przez pomniejsze narody zamieszkujące Wyspy Brytyjskie. Innymi słowy: europejskie peryferie jako ogół niejednolitych „marginalnych” regionów oferują znaczne możliwo- 
ści porównania, ale pisanie ich całościowej historii prawdopodobnie zbytnio nie wzbogaciłoby naszego poznania.

Pojęcia „centrum”, ,peryferie” i pośrednie „semiperyferie” zawsze są terminami relatywnymi i jedynie „miękkimi” (soft), tworzonymi na podstawie specyficznego spojrzenia na region, kontynent czy świat. Z globalnego punktu widzenia, w ciągu ostatnich trzech tysiącleci centra rozwoju ludzkości radykalnie się zmieniły, stąd też nawet dominacja Zachodu nie była tak jednoznaczna, za jaką przyzwyczailiśmy się ją uważać w ramach myślenia europocentrycznego. Biorąc pod uwagę znaczenie Chin, Indii, Mezopotamii, Egiptu, Ziemi Świętej, Kalifatu Arabskiego, Persji, Imperium Osmańskiego, później Stanów Zjednoczonych Ameryki i Rosji w dziejach, centralna pozycja Europy Zachodniej w skali światowej redukuje się do kilku stuleci istnienia nowożytnych imperiów kolonialnych. Jeśli dodamy do tego antyczne Imperium Rzymskie, to - w ramach świata śródziemnomorskiego - otrzymamy jeszcze dodatkowo kilka stuleci starożytności. Średniowieczna Europa Zachodnia takiej pozycji z politycznego i mocarstwowego punktu widzenia z pewnością nie miała. Jeśli jednak weźmiemy pod uwagę aspekt kulturowy, to także ona może się jawić jako miejsce kształtowania się cywilizacji zachodniochrześcijańskiej i jako obszar powstawania uwarunkowań jej późniejszej ekspansji ogólnoświatowej. Czy tym centrum była jednak rzeczywiście Europa Zachodnia? Czy należała do niej antyczna Grecja i Bizancjum, czy należały do niej również same Włochy? Czy nie byłoby właściwsze mówienie o śródziemnomorsko-atlantyckim makroregionie Europy?

Kraje Europy Środkowej do tego makroregionu nie należały, ponieważ (z wyjątkiem mniejszych peryferyjnych obszarów na południe od Dunaju) odległe im były doświadczenia starożytnego Cesarstwa Rzymskiego i od chwili, kiedy znalazły swoje miejsce na kartach historii, wyróżniały się tym, że były położone z dala od głównych (morskich) ośrodków życia handlowego i kulturalnego. Nie były jednak na tyle oddalone, aby przez półtora tysiąclecia nie były tylko przedmiotem ekspansji mocarstwowej, ale także efektywnego przenikania wpływów kulturalnych z Zachodu oraz ze Wschodu. Usytuowanie między Imperium Franków, Świętym Cesarstwem Rzymskim Narodu Niemieckiego, a następnie zjednoczonymi Niemcami z jednej strony oraz Bizancjum, Imperium Osmańskim, a później zjednoczoną Rosją ze strony drugiej stało się charakterystycznym rysem rozwoju Europy Środkowej. Jednak nie tylko przestrzeń „między Niemcami a Rosją", ale trwałe położenie między Zachodem a Wschodem było i jest znamienną cechą geopolityczną i kulturową Europy Środkowej. $Z$ tego podejścia wynika, że od wczesnego średniowiecza Europę Środkową tworzyły cztery państwa złożone (composite states), czyli ziemie 
polskie, czeskie, austriackie i węgierskie. Wyodrębnienie tego obszaru jako Europy Środkowo-Wschodniej ma charakter wtórny i dokonuje się dopiero wówczas, kiedy do Europy Środkowej (Mitteleuropa) mają być włączone także tereny Niemiec, które jednakże zasadniczo należały i należą do regionu zachodnioeuropejskiego. Wspólną cechą średniowiecznej i nowożytnej historii polsko-czesko-austriacko-węgierskiego makroregionu stała się jego peryferyjna lub względem Wschodu pośrednia, semiperyferyjna pozycja w historii Europy. Na centralną, w przeważającej mierze śródlądową część kontynentu na początku, kiedy zapisano ją na kartach historii, oddziaływało wprawdzie zarówno centrum wschodnie (bizantyjskie), jak i zachodnie (karolińskie i ottońskie), ale wpływy zachodnie tutaj w sposób jednoznaczny i trwale przeważyły. W odróżnieniu od regionu śródziemnomorskiego i atlantyckiego powstające tutaj państwa nie miały takiej siły ekonomicznej i politycznej, która pozwoliłaby im aspirować do roli hegemona w Europie. Aczkolwiek z tego obszaru pochodziło wiele wybitnych postaci, które na stałe zapisały się w historii światowej nauki i sztuki, to poza pewnymi wyjątkami (związanymi z kulminacyjnym okresem Rzeczypospolitej i z cesarską Pragą czy Wiedniem) nie ujawniły się tutaj tak silne impulsy ekonomiczne i uniwersalno-kulturowe, które w zasadniczy sposób wpłynęłyby na cały kontynent. Odwrotnie, wielkie kompleksy stylów - romański, gotycki, renesansowy i barokowy - były przejmowane z zachodu i południa Europy i w sposób twórczy przystosowywane do warunków krajowych. Także bardziej rozwinięte formy życia gospodarczego, prawnego i społecznego zazwyczaj napływały z zachodu i z południa. Przewaga recepcji kulturowej czy w szerszym sensie cywilizacyjnej nad oddziaływaniem kulturowym należy do konstytutywnych i stałych rysów Europy Środkowej.

W odróżnieniu od zachodniej i większej części wschodniej Europy Europa Środkowa charakteryzuje się nie tylko odmiennością etniczną, ale również związaną z nią różnorodnością państwową i polityczną. Powstanie porównywalnie wpływowych państw około roku 1000 prowadziło do tego, że Polska, Czechy, Austria i Węgry mogły wzajemnie utrzymywać równowagę sił. Trwałym zjawiskiem stały się długookresowo kończące się niepowodzeniem dążenia do integracji obszaru środkowoeuropejskiego, gdzie zmieniały się dynastie Przemyślidów, Piastów, Habsburgów, Andegawenów, Luksemburgów, węgierskiego rodu magnackiego Hunyadi i Jagiellonów, co przez całe średniowiecze świadczyło o tym, że żadne z tych państw nie posiadało takiej przewagi nad pozostałymi, aby było zdolne na dłuższy czas zjednoczyć przynajmniej zasadniczą część makroregionu. Dopiero Habsburgowie, kiedy udało im się zdobyć drugie i decy- 
dujące centrum mocarstwowe w Europie Zachodniej, potrafili doprowadzić do zmiany równowagi i zapoczątkowali drogę wczesnonowożytnej integracji. Średniowieczna kontynuacja współzawodnictwa niezależnych państw - przy zagranicznopolitycznym ukierunkowaniu Polski na Wschód - w XVI w. stopniowo przekształciła się we wzajemną rywalizację najważniejszych terytorialnych części składowych monarchii habsburskiej (po rozbiorach Polski obejmującej także część jej terytorium) i w XIX w. przybrała postać nacjonalistycznych i prawnopaństwowych sporów między narodami w ramach jednego związku państw.

Tendencja do integracji całego makroregionu lub częściowych subregionów tworzy jedną z zasadniczych cech ciągłego rozwoju Europy Środkowej, aczkolwiek źródła integracji były różnorodne i konkurowały ze sobą nawzajem. Stosunkowo najdłużej istniało węgierskie państwo ponadnarodowe, w swym rdzeniu utworzone na gruzach wschodniej części Wielkich Moraw w X w. Przez stulecia jego silną stroną była struktura terytorialna i społeczna, dzięki której udało się zatrzeć różnice narodowościowe zamieszkujących go zróżnicowanych etnicznie mieszkańców; jednak próba zjednoczenia tego państwa pod względem językowym poprzez przymusową madziaryzację w XIX w. była zasadniczą przyczyną jego zaniku w 1918 r.

Państwo czeskie powstawało jednocześnie z państwem węgierskim, ale na o wiele mniejszym terytorium, dlatego jego rdzeń (Czechy i Morawy) mógł pozostać aż do niemieckiej kolonizacji w XIII w. pod względem etnicznym zdecydowanie czeski. Korona Czeska czy też Korona Świętego Wacława, potwierdzona dekretami króla czeskiego Karola IV w połowie XIV w., była już państwem wieloetnicznym, w którego północnej połowie - na Śląsku oraz w Górnych i Dolnych Łużycach - przeważali Niemcy obok stanowiących mniejszość narodów słowiańskich (Polaków, Czechów i Serbów Łużyckich). Utrata terenów północnych w okresie wojny trzydziestoletniej i wojen śląskich oznaczała faktyczny rozpad Korony Czeskiej, ponieważ państwo czeskie ponownie ograniczyło się do Czech i Moraw z peryferyjnymi resztkami śląska.

Istotną siłą integracyjną stała się Polska, która po swoim zjednoczeniu w XIV w. z powodzeniem prowadziła ekspansję na wschód, co przybrało formę przyjęcia dynastii z przyłączonych ziem (litewskich); na obszarze środkowoeuropejskim stanowiło to jedyny w swoim rodzaju sygnał, że nie chodzi o najazd na ziemie litewskie ze strony Polski, lecz o dobrowolne zjednoczenie. W porównaniu z tym konsekwencje rozbiorów Rzeczypospolitej -będącej przez długi okres czasu czynnikiem stabilizacyjnym w Europie Środkowej - dotknęły cały makroregion, 
ponieważ zmniejszyły go o zabór pruski i rosyjski, po czym Europa Środkowa praktycznie utożsamiła się z monarchią habsburską, obejmującą również ziemie zaboru austriackiego (Galicję).

Najbardziej złożony przykład próby integracji zasadniczej części Europy Środkowej stanowi właśnie monarchia habsburska. W odróżnieniu od sąsiednich państw, w których szkielet dużej formacji państwowej tworzyły najsilniejsze kraje (Polska, Czechy, centralne Węgry), powstały w tym przypadku związek państw skupił się wokół swojego najsłabszego ogniwa. Dziedziczne kraje austriackie około 1526 r. zarówno pod względem swego znaczenia strategicznego i politycznego, jak i potencjału ekonomicznego nie dorównywały Królestwu Czeskiemu czy Węgierskiemu. Jedynie siła dynastii habsburskiej, rozciągającej się między Europą Środkową a Zachodnią, mogła zrównoważyć te niedostatki. Podstawa wyjściowa związana $\mathrm{z}$ faktem, że monarchia powstała jako połączenie trzech samodzielnych państw, w wyniku polityki centralizacyjnej Habsburgów była systematycznie podawana w wątpliwość, co na dobrą sprawę właściwie stanowiło zaprzeczenie dotychczasowego zrównoważonego współistnienia państwa czeskiego, austriackiego, węgierskiego i polskiego w Europie Środkowej. Centralizacja niosła ze sobą pewne pozytywy w postaci modernizacji i wywarła korzystny wpływ podczas organizacji obrony Europy Środkowej przeciwko Turkom. Miała jednak też ciemne strony, ponieważ jej istotą była nagła zmiana dotychczasowych kierunków rozwojowych.

Właśnie w decydującym okresie XVI i na początku XVII w. pojawiła się w Europie Środkowej co najmniej teoretyczna możliwość utworzenia odmiennego modelu organizacji społeczeństwa i państwa aniżeli ten, jaki istniał w Europie Zachodniej. W okresie wojen religijnych i masowego mordowania czy wypędzania innowierców na Zachodzie, na obszarze polsko-czesko-węgierskim rozwinęła się swoista kultura polityczna szerszego (stanowego) udziału we władzy i powstała praktyka tolerancji religijnej w realnie istniejącym środowisku wielowyznaniowym. Polska, Morawy i Siedmiogród na kilka dziesięcioleci stały się przykładem funkcjonującego z powodzeniem współistnienia katolików, ewangelików i zwolenników radykalnych prądów religijnych. Do tej sytuacji zachodnioeuropejska Holandia dojrzała dopiero w ciągu XVII w. W Czechach w 1609 r. tej koegzystencji nadano ściśle ustalone ramy prawne, co tworzyło przesłanki dla zachowania i dalszego rozwoju tego modelu współistnienia. Działania kontrreformacyjne, związane przede wszystkim z dynastią habsburską i jej zwolennikami, doprowadziły w 1620 r. do klęski czeskiego powstania stanowego, a wraz z nim do upadku pomyślanego na wielką skalę, lecz politycznie niewystarczająco popartego projektu konfederacji krajów środkowoeuropejskich. Fatalny 
przebieg wojen w XVII w. definitywnie zniweczył potencjał inspiracyjny tego środkowoeuropejskiego modelu, ze szkodą dla całej Europy.

Habsburgom już nie starczyło sił, by doprowadzić do całkowitej porażki stanów węgierskich, dlatego rozwiązanie z początku XVIII w. było bliskie kompromisowi. Barokowa monarchia absolutystyczna, oparta na powiązaniach dworu wiedeńskiego $\mathrm{z}$ arystokratycznymi ośrodkami politycznymi w poszczególnych krajach, przyniosła tymczasową stabilizację, nie mogła jednak zapewnić sobie trwałego istnienia. Już epoka oświecenia i dążenia do racjonalnego kierowania losami ludzi i narodów z jednego centrum politycznego, ich kulturowej i językowej unifikacji świadczyły o tym, że monarchia habsburska nie jest czynnikiem zapewniającym ciągłość i że ten sposób integracji jest sprzeczny z długookresowymi latentnymi kierunkami rozwoju środkowoeuropejskiego. $Z$ powodu niemożności rozwiązania problemów etnicznych i związanych z nimi trudności społecznych w inny sposób niż ponawiane próby wprowadzenia absolutyzmu, monarchia habsburska rozpadła się w wyniku emancypacyjnych dążeń narodów środkowoeuropejskich. Próby umocnienia upadającej monarchii poprzez serię przegranych, jak się okazało, wojen i późniejszą ekspansję na Bałkany mogły prowadzić jedynie do krwawego upadku rządów Habsburgów w wirze wydarzeń I wojny światowej.

Istnienie monarchii habsburskiej bywa uważane przez jej późniejszych entuzjastów za jedno z najważniejszych znamion Europy Środkowej i niekiedy jest nawet prezentowane jako wzór nowoczesnej integracji całego kontynentu. W rzeczywistości opierało się na akurat odwrotnych zasadach niż te, jakie deklaruje współczesna Unia Europejska. Te konstytutywne zasady szczególnie mocno uwidaczniały się w sytuacjach kryzysowych; była to krwawa przemoc zamiast dobrowolności, konfiskata zamiast respektowania praw majątkowych, centralizacja władzy zamiast partycypacji i subsydiarności, prześladowania innowierców zamiast wolności sumienia. Aczkolwiek Habsburgowie, począwszy od niezwykle zdolnego organizatora Ferdynanda I, ze swojego punktu widzenia postępowali konsekwentnie, czyli w ramach władzy dynastycznej dążyli do zachowania ciągłości, to ich działalność w ciągu czterech stuleci istnienia monarchii w zasadzie naruszała ciągłość rozwoju środkowoeuropejskiego.

Pomimo tego monarchia habsburska jako czynnik modernizacyjny i wraz z Polską najważniejsza tama ochronna przeciwko ekspansji tureckiej jeszcze pod jednym względem odegrała pozytywną rolę. Po tym, jak w drugiej połowie XIX w. udało się wbrew woli władcy przeforsować strukturę konstytucyjną, narody mieszkające na tym obszarze powróciły do dawnego pluralizmu. Ich elity - zwłaszcza polska, czeska i węgierska - uczyły się roli uczestnika rozgrywek politycznych toczących się 
względem dworu oraz w stosunku do pozostałych graczy na scenie politycznej, dostosowanych do warunków nowoczesnych czasów. Niezależnie od wszelkich niepowodzeń przyswoiły sobie umiejętność samodzielnego decydowania i rządzenia, co dało o sobie znać po $1918 \mathrm{r}$. Nie ulega wątpliwości, że zwłaszcza w nowych państwach wielonarodowych (także w Polsce i Czechosłowacji), powtarzały one niektóre błędy swych wcześniejszych władców, dołączając do nich nowe, za co w II wojnie światowej ciężko zapłaciły.

Jednak już od początku XX w. Europa Środkowa musiała się zmierzyć z kolejnym brakiem ciągłości. Tendencje nacjonalistyczne w różnym stopniu były charakterystyczne dla wszystkich narodów tego makroregionu i pozostawało sprawą otwartą, jak sobie z nimi potrafią poradzić. Rozbieżności między wysokimi ambicjami przedstawicieli narodu węgierskiego i niemieckiego, które miały w monarchii habsburskiej szczególne przywileje, i narodami przeważnie mniej licznymi, ale gospodarczo silniejszymi przybrały szczególnie ostrą postać. Nieumiejętność rozwiązywania problemów prawnopaństwowych i narodowych w monarchii dualistycznej, zwłaszcza napięcie w stosunkach czesko-niemieckich oraz wzrastający antysemityzm przed I wojną światową oraz po jej zakończeniu, tworzyły sprzyjające warunki dla narastania szowinizmu i powstania nazizmu. Nieludzkie wizje o prawie „narodu panów” do życia na terenie „oczyszczonym” z Żydów i Słowian przyniosły Europie Środkowej niespotykane do tej pory okrucieństwo i masowe mordy przedstawicieli „rasy podrzędnej” i „narodów niepełnowartościowych”. Jedynie sporadycznie problematyczne i napięte, przeważnie jednak spokojne lub przynajmniej zadowalające współistnienie różnych narodów w Europie Środkowej, zmieniło się najpierw po stronie ofiar, potem - w konsekwencji przegranej wojny - również po stronie sprawców w rozpaczliwą walkę o przetrwanie. Europa Środkowa stała się miejscem nadzwyczaj brutalnego eksperymentu wprowadzania „nowego porządku” i wbrew swej woli na krótki czas z obszaru semiperyferyjnego zmieniła się w centrum ludobójczych przemian całego kontynentu. Ludobójstwo i przymusowa migracja w latach 1938-1948 wprawdzie przerwały ciągłość tysiącletniego rozwoju etnicznego, jednak paradoksalnie zintensyfikowały tendencje odnowy i wzmocnienia państw narodowych.

Ledwo zdążył upaść jeden zbrodniczy reżim totalitarny, kiedy to środkowoeuropejski makroregion został po raz pierwszy w swojej historii tak intensywnie narażony na nacisk ze strony nowych supermocarstw, którym poszczególne państwa podporządkowały się nie tylko pod względem ekspansywnym i politycznym, ale częściowo również intelektualnym. Przedzielenie Europy „żelazną kurtyną” spowodowało, że 
do Europy Środkowej zostały także przyłączone Niemcy Wschodnie, co świadczyło o tym, iż poszukiwanie form przetrwania w nowych warunkach było zdeterminowane przede wszystkim okolicznościami obiektywno-geopolitycznymi. Pod jarzmem sowieckim, tak samo jak Niemcy Wschodnie, znaleźli się także Polacy, Czesi, Słowacy i Węgrzy - niezależnie od tego, czy przedtem w ich centrum przeważały lewicowo czy też prawicowo zorientowane elity. Europa Środkowa - w krótkim czasie po raz drugi jako pas buforowy między Zachodem a Wschodem - stała się zarzewiem napięcia i obszarem potencjalnego konfliktu między państwami należącymi do Paktu Północnoatlantyckiego i Układu Warszawskiego. O mały włos sama nie stała się ofiarą podczas rozwiązywania konfliktu jądrowego pomiędzy supermocarstwami.

Pomimo wszelkich starań nowego hegemona zmierzających do bezwarunkowego podporządkowania sobie Polski, Czechosłowacji i Węgier sowietyzacja tych krajów miała jedynie powierzchowny i chwilowy charakter. W formach sprzeciwu w latach 1953, 1956, 1968, 1980 i 1989 uwidoczniła się zaburzona ciągłość rozwoju środkowoeuropejskiego, czyli dążenia poszczególnych państw do samodzielności, a ich narodów do samostanowienia. Lata osiemdziesiąte XX w. ponownie przesunęły Europę Środkową, przede wszystkim jednak Polskę czasów „Solidarności”, do centrum wydarzeń europejskich. Skoro tylko gospodarczo podupadający Związek Radziecki opuścił obszar środkowoeuropejski, państwa tego makroregionu pod hasłami „transformacji” i ,powrotu do Europy” rzeczywiście zmieniły swoją pozycję, przechodząc do położenia semiperyferii Zachodu ze wszystkimi pozytywnymi aspektami recepcji demokratycznych form rządzenia i podnoszenia poziomu życia, ale także z negatywnymi konsekwencjami wyraźnej zależności ekonomicznej. Jednak poprzednie cztery dziesięciolecia rządów komunistycznych pozostawiły po sobie narodom środkowoeuropejskim oprócz ciążącego dziedzictwa w sferze gospodarczej, politycznej i psychologicznej paradoksalnie także jedną bardzo cenną spuściznę. Mianowicie doświadczenie tego samego systemu rządów i eksperymentu „klasowo” równego społeczeństwa. Jak wyraźnie dowodzi m.in. głęboka przemiana wcześniej napiętych stosunków między Polakami i Czechami, doświadczenia te istotnie przyczyniły się do tego, że przedstawiciele poszczególnych krajów środkowoeuropejskich uświadomili sobie doniosłość przyjaznego współistnienia, a ich mieszkańcy zaczęli pokonywać głęboko zakorzenione negatywne heterostereotypy.

Jeśli polityczny policentryzm potraktujemy jako charakterystyczną cechę rozwoju na obszarze środkowoeuropejskim, to możemy stwierdzić, że w tym makroregionie w XX w. ukształtowała się w zasadzie prężna „wylęgarnia” narodów i państw narodowych. Proces, który został 
zapoczątkowany w 1918 r. powstaniem Polski, Czechosłowacji, Węgier oraz ponownie małej Austrii na gruzach trzech mocarstw, był kontynuowany aż do lat dziewięćdziesiątych XX w.; wówczas nastąpił zanik systemu wersalskiego i jałtańskiego w wyniku rozpadu dwóch państw wielonarodowych (Czechosłowacji i Jugosławii) i na scenę Europy Środkowej wkroczyły także Słowacja i Słowenia. Dwa wcześniej „narody niepaństwowe" w ciągu minionych dwóch dziesięcioleci wykazały odpowiednią pewność siebie, ujawniły umiejętność rządzenia (przynajmniej w warunkach pokojowych pod ochronnym parasolem Unii Europejskiej i Paktu Północnoatlantyckiego) i w sensie ekonomicznym oraz kulturowym przeżyły swoją success story. Odnowione państwo czeskie miało prawie takie same granice, jak tysiąc lat wcześniej. Zresztą tak samo jak zjednoczone Niemcy, które powróciły w zasadzie na swoje zachodnioeuropejskie tereny, które Niemcy zamieszkiwali przed wielką kolonizacją w XIII w.

Na razie zamknęło się koło historii, jakie zatoczyła Europa Środkowa w drugim chrześcijańskim tysiącleciu. Europa Środkowa - obszar buforowy między mocarstwami Zachodu i Wschodu - przeżyła w XX w. eksplozję przemocy z obu stron i doświadczyła, co znaczy na krótko znaleźć się w centrum dziejów - bądź jako pasywny obiekt wydarzeń o zasięgu światowym, bądź też jako aktywny czynnik, potrafiący przedkładać propozycje do pokojowego rozwiązywania problemów, jakie dojrzały właśnie w tej części kontynentu. W tysiącletnim rozwoju były to właściwie tylko chwile, które nie mogły zasadniczo zmienić pozycji (semi)peryferyjnej Europy Środkowej między mocarstwami atlantyckimi i mocarstwami położonymi nad Pacyfikiem.

Obecnie ta część kontynentu jest ponownie rozdzielona na kilka małych - przeważnie monoetnicznych - państw, tylko ich liczba poniekąd się zwiększyła. Ich wspólny koncert może trwać nadal, ale należy mieć świadomość tego, że coraz silniej będą się odzywać głosy nowo przybyłych migrantów i że odbywa się on nie tylko pod batutą Unii Europejskiej, ale także i przede wszystkim globalnego kapitału. Do jakiego stopnia Europa Środkowa zachowa dominujące rysy swojego rozwoju w związku ze zmienioną partyturą i pod kierunkiem nowego dyrygenta, pokaże być może już najbliższa przyszłość. W każdym razie dla historyków nowych generacji to będzie fascynujący temat.

Z jęz. czeskiego przełożyła Elżbieta Baron 